\title{
TRADISI PENULISAN DALAM PROSES TRANSFORMASI HADIS Mustofa 'Umar
}

Fakultas Syariah dan Hukum UIN Alauddin Makassar

e-mail:mustafa.syariah2012@gmail.com

\begin{abstract}
The Orientation of present paper to be researching and discussing on hadith transformation through writing tradition. In the early of this process, dominant paradigm in classical hadith scholars in hadith transformation based on oral tradition without writing tradition until second half century. This not without strong argument, there is hadith statement on prohibiting of hadith writing. This phenomena has impact on authenticity the materials of hadith after their codification. In historically context, writing of hadith happened in middle of conflict moslem in political and school of thought. The alleged wholesale fabrication of hadith in seen as result of the activities of group of scholars and foremost as result of interpretation from point of view of praxis.
\end{abstract}

\begin{abstract}
Abstrak: Orientasi dari paper sekarang ini untuk meneliti dan mendiskusikan tentang transformasi hadis sepanjang tradisi penulisan. Dalam proses awal dari proses ini, paradigma yang dominan di kalangan ulama hadis dalam transformasi hadis berdasarkan pada tradisi lisan tanpa tradisi tulis hingga paroh abad kedua. Ini bukanlah tanpa argumen yang kuat, ada pernyataan hadis mengenai larangan penulisan hadis. Fenomena berpengaruh pada otensitas material-material hadis setelah kodifikasi mereka. Dalam konteks sejarah, penulisan hadis terjadi di tengah konflik kaum Muslim di bidang politik dan mazhab pemikiran. Terjadi pemalsuan hadis besar-besaran yang dilihat sebagai hasil dari aktivitas-aktivitas kelompok ulama dan terkemuka sebagai hasil dari interpretasi berdasarkan sudut pandang praksis.
\end{abstract}

Keywords: hadis, sunnah, al-Quran, Kutubi, ahl al-ra'y, ahl alhadīs.

\section{A. Pendahuluan}

Siginifikansi hadis sebagai sumber otoritatif kedua setelah al-Quran, menempati posisi sentral dalam seluruh kajian agama. Otoritas Muhammad di luar al-Quran tak terbantahkan dan mendapat legitimasi melalui wahyu. ${ }^{1}$ Secara faktual prilaku beliau merupakan menifestasi al- 
Quran yang pragmatis. ${ }^{2}$ Dalam beberapa literatur, ditemukan bahwa sunnah berasal dari sumber yang sama, perbedaan kedaunya hanya pada bentuk dan tingkat otentisitasnya, bukan pada substansinya. Dengan demikian sunnah dikategorikan sebagai wahyu ghayra mațu. ${ }^{3}$

Pada masa awal perkembangan Islam, transformasi hadis lebih bersifat peneladanan langsung tanpa melibatkan rumusan-rumusan verbal. Para sahabat mencoba untuk hidup sesuai dengan ajaran-ajaran Nabi, sehingga diktum dan fakta Nabi yang aktual sering kali terjalin secara halus dan tidak dapat dibedakan. ${ }^{4}$ Demikian halnya pada generasi berikutnya, sehingga tradisi rasul begitu melekat dalam prilaku sahabat yang direkam oleh generasi berikutnya. Namun demikian transformasi semacam itu tidak semudah sebagaimana yang digambarkan, mengingat kondisi obyektif sahabat yang heterogen. ${ }^{5}$ Heterogenitas tersebut bukan tidak membawa masalah tentang apa yang datang dari Nabi, karena sepeninggal beliau orientasi praktis ini berkembang luas dan tumbuh semakin kompleks dengan kecepatan yang mencengangkan dan tanpa preseden. ${ }^{6}$

Fenomena tersebut berimbas pada munculnya masalah serius tentang keabsahan segala sesuatu yang datang dari Nabi. Terutama banyaknya pemalsuan hadis yang disebabkan oleh terjadi pertentangan politik dan munculnya banyak faksi dalam beberapa aliran pemikiaran Islam, baik dalam teologi, fiqh, filsafat, maupun tasawuf. Tradisi lisan dalam transformasi hadis telah mempersulit upaya verifikasi terhadap hadis-hadis yang beredar di kalangan umat Islam. Kondisi semacam ini menjadi objek kajian serius di kalangan sarjana Barat, beberapa hyposa dan tesis mereka bermuara pada keraguan terhadap autentisitas dan validitas hadis Nabi. ${ }^{7}$ Namun demikian, bagaimana tentang tradisi tulisan di kalangan periwayat dalam mentransformasikan hadis akan menjadi sorotan dalam artikel ini.

\section{B. Upaya Penghimpunan dan Penulisan Hadis}

Sejak awal munculnya Islam, Muhammad memegang hak prerogratif keagamaan setelah Allah. Para sahabat beliau selalu berkonsultasi kepada Nabi tentang masalah-masalah yang muncul. Dalam kondisi masyarakat yang ummī (tidak adanya budaya baca tulis), para sahabat lebih mengandalkan hafalan mereka. ${ }^{8}$ Akan tetapi bukan berarti pada saat itu tradisi penulisan tidak ada sama sekali. Sejak pra-Islam, tradisi tulisan 
sudah banyak dikenal dalam pagan Arab, terutama di kalangan penyair. Meskipun demikian, mereka lebih membanggakan kekuatan hafalan dan menganggap aib terhadap tulisan. ${ }^{9}$ Bukti lain dari terdapatnya tradisi tulisan di kalangan Arab adalah diharuskannya setiap tawanan Badr untuk mengajarkan baca tulis kepada sepuluh anak muslim. ${ }^{10}$ Terdapat sejumlah penulis wahyu yang menyertai Nabi sekitar 40 orang, ${ }^{11}$ juga terdapat majlis 'Abd Allāh ibn Sa'ad yang mengajarkan tulisan di serambi masjid (Șuffah).12 Sa'ad ibn 'Abd Allāh ibn Auf memiliki kumpulan hadis sebagai tulisan tangan sendiri,13 Jābir memiliki lembaran sejenis, ${ }^{14}$ terdapat "Ṣāhifah Ṣādiqah" yang ditulis dan dikumpulan oleh 'Abd Allāh ibn 'Amr ibn 'Aș yang berisi sekitar seribu hadis. ${ }^{15}$ Nabia Abbott'16 dan M.M. Azmi ${ }^{17}$ memaparkan secara rinci tentang bukti adanya tradisi tulisan pada masa awal Islam. Namun bukti-bukti yang diajukan keduanya dibantah oleh Juynboll bahwa bukti manuskrip-manuskrip tersebut tidak realis (unearthed) dan hanya bersifat dugaan sebagai teks-teks kuno yang mudah dipalsukan pada generasi berikutnya. ${ }^{18}$ Nampaknya bukti-bukti yang diajukan baik Azmi maupun Nabia Abbott terdapat kelemahan jika diuji secara filologis.

Dalam kaitannya dengan transmisi hadis, pada masa awal Islam, para sahabat saling tukar menukar informasi tentang segala sesuatu yang datang dari Nabi. Tradisi lisan dalam periwayatan hadis dilatarbelakangi oleh kontradisi tentang hadis pelarangan dan pembolehan penulisan hadis. Meskipun hadis yang melarang menulis hadis jumlahnya lebih sedikit, ${ }^{19}$ daripada hadis-hadis yang membolehkan, ${ }^{20}$ namun demikian para sahabat lebih berpegang pada hadis tentang pelarangan penulisan hadis dan lebih mengandalkan pada hafalan, kecuali terdapat beberapa kasus ditemukannya beberapa tulisan tentang hadis. Alasan untuk tidak menulis secara umum karena ditakutkan akan bercampur dengan alQuran. ${ }^{21}$ Setelah mengalami perluasan wilayah Islam, Rasulullah sering mengutus para sahabatnya untuk mengajarkan agama ke berbagai kawasan. Akibatnya banyak sahabat yang terkonsentrasi pada wilayahwilayah baru dan berkembang menjadi basis baru bagi perkembangan hadis. Materi hadis mulai terdistorsi oleh interfensi pendapat pribadi para sahabat, karena dalam majlis ilmu terkadang para sahabat memberikan materi tentang syair-syair masa jahiliyah. ${ }^{22}$ Nampaknya pada masa awal Islam penyebaran hadis agak lebih leluasa, seiring dengan semangat 
penyebaran Islam, meskipun terkesan tidak terkendali dengan munculnya beberapa tambahan pendapat pribadi. Fenomena semacam ini pernah dikecam oleh 'Ali ibn Abī Țālib terhadap tulisan-tulisan yang memuat pendapat-pendapat para ulama yang diibaratkan pada umat sebelumnya. $^{23}$ Sebagaimana diriwayatkan bahwa ditemukan dalam șahifāh terdapat pendapat dan cerita dari Ibn Dardā' sendiri. ${ }^{24}$

Adapun pada masa empat khalifah, kondisi semacam itu mengalami pergeseran, khususnya tentang tradisi periwayatan dan penulisan hadis. Mereka lebih membatasi penyebaran hadis secara bebas. Sebagaimana Abū Bakar meminta saksi teradap informasi tentang satu hadis yang datang kepadanya, ${ }^{25}$ demikian juga yang dilakukan oleh 'Umar. ${ }^{26}$ Sementara 'Alī ibn Abī Ṭālib meminta sumpah bagi siapa yang meriwayatkan hadis dihadapannya. ${ }^{27}$ Kondisi semacam ini diperketat pada masa kekuasaan 'Umar, dia membakar kumpulan hadis yang ada padanya sejumlah lima ratus hadis. ${ }^{28}$ Dia juga mengirim surat edaran yang berisi perintah untuk memusnahkan setiap catatan hadis. ${ }^{29}$ Pada kesempatan lain 'Urwah ibn Zubayr meriwayatkan bahwa ketika 'Umar ibn Khațāa hendak menulis hadis, dia bermusyawarah dengan para sahabat, dan mereka menyepakati ide 'Umar tersebut, namun setelah merenungkan, suatu hari dia berkata: "Saya bermaksud menulis sunnah, tetapi kemudian saya teringat kembali orang-orang sebelum kalian menulis kitab dan mengabaikan Kitab Allah. Demi Allah saya tidak akan menutupi kitab Allah dengan apapun."30 Bahkan 'Umar tidak segan-segan untuk menghukum orang yang melanggar seruannya tersebut. ${ }^{31}$ Ketakutan 'Umar didasarkan pada sikap umat Islam akan mengesampingkan dan meremehkan al-Quran jika diperbolehkan penulisan hadis-hadis Nabi. ${ }^{32}$ Sebenarnya kekhawatiran 'Umar lebih didasarkan pada pengalaman tradisi kaum Yahudi yang membuat mașnat yang menggantikan posisi Taurat, ${ }^{33}$ karena dia pernah ditegur keras oleh Rasulullah berkenaan kitab Taurat yang dia baca. ${ }^{34}$

Pasca-empat khalifah, dinamika periwayatan hadis nampak lebih longgar, ${ }^{35}$ meskipun demikian, secara umum para sahabat masih mengikuti tradisi sebelumnya yaitu mengekang penulisan hadis. Abū Kasīir al-Ghubri meriwayatkan bahwa Abū Hurairah berkata: "Hadis-hadis hendaknya disembunyikan atau tidak ditulis." 36 Pada kesempatan lain dia menyatakan bahwa dirinya tidak menulis hadis. ${ }^{37}$ Terdapat sikap 
inkonsistensi Abū Hurairah, karena dia memiliki manuskrip (șahịfah) yang berisi hadis-hadis. ${ }^{38}$ Șahïfah tersebut berisi 140 hadis yang diriwayatkan oleh muridnya Humam ibn Munabbih. ${ }^{39}$ Ketika ditanya mengapa dia tidak menuliskan hadis, ia menjawab: "jika orang menulis sesuatu, maka ia akan menaruh kepercayaan terhadap tulisan itu." 40 'Abd Allāh ibn Muslim meriwayatkan bahwa Sa'id ibn Jubayr membenci penulisan. ${ }^{41}$ Ibn 'Abbas juga melarang menulis hadis. ${ }^{42}$ Hal yang sama dialami oleh, 'Abd Allāh ibn 'Umar yang membenci tulisan. ${ }^{43}$ Demikian halnya Abū Mūsa al-Asy'arī lebih mengutamakan hafalan. ${ }^{44}$ Hasan ibn 'Ali al-Hasan menjelang wafatnya memerintahkan kepada budaknya untuk menyalakan tungku dan membakar seluruh kitab kecuali al-Quran saja yang tertinggal. ${ }^{45}$ Kondisi semacam itu juga dirasakan oleh Yahya ibn Sa'id berkata: "Saya mendapati para ulama menolak penulisan." 46

Ketabuan untuk menulis hadis terus berlanjut pada periode tabi'in dan telah menjadi fenomena umum, bahkan seolah telah menjadi ketentuan resmi untuk tidak menulis sesuatu kecuali al-Quran. Sikap tabi'in ini tidak lain adalah mengikuti para pendahulu mereka. ${ }^{47}$ Budaya pengakangan terhadap tradisi tulisan terutama pada generasi tabi'in awal (kibār al-Tabiīin) sampai menjelang akhir abad pertama hijriyah. Di antara mereka adalah 'Ubaidah ibn 'Amr al-Salmāni, yang tidak rela seseorang menulis hadis darinya. ${ }^{48}$ Ibarāhīm ibn Yazīd memberi nasehat untuk tidak mengabadikan apa yang diajarkan darinya dengan tulisan. ${ }^{49}$ Ibrāhīm al-Nukha'i membenci penulisan di dalam kertas, dan dia sama sekali tidak pernah menulis, ${ }^{50}$ bahkan dia melarang salah satu muridnya untuk menulis. ${ }^{51}$ Kebencian terhadap tulisan semakin membudaya setelah merebaknya pendapat-pendapat pribadi di kalangan para ulama.

Babakan baru diawali oleh 'Umar ibn 'Abd al-'Azīz yang memerintahkan kepada para ulama untuk menulis hadis dan diperintahkan untuk mengirim kepadanya. ${ }^{52}$ Keputusan 'Umar ibn 'Abd al-'Azīz telah menjadi keputusan resmi negara dengan menyebarkan surat edaran ke beberapa wilayah untuk membudayakan pemeliharaan sunnah melalui tulisan..$^{53}$ Diriwayatkan bahwa dia telah mengirim perintah kepada Murrah ibn Kasīr untuk menulis hadis-hadis baginya, ${ }^{54}$ dia juga menulis surat kepada Abū Bakar ibn Muhammad ibn Hazm: "catatlah setiap hadis Nabi yang ada padamu, dan kirimkan juga kepadaku apa saja yang diriwayatkan dari 'Umar sebab saya khawatir hadis-hadis itu akan 
hilang." ${ }^{55}$ Adapun orang pertama yang memenuhi anjuran dan perintah khalifah 'Umar adalah seorang ulama Hijaz dan Syam yaitu Muhammad ibn Muslim ibn Șịhāb al-Zuhrī. ${ }^{56}$ Pada perkembangan selanjutnya, al-Zuhrī memegang otoritas kunci dalam sistem jaringan periwayatan hadis.

Kebijakan 'Umar ibn 'Abd al-'Azīz telah membawa dampak yang luar biasa terhadap perkembangan tardisi tulis. Kesadaran akan pentingnya penulisan hadis sangat dirasakan para ulama. Keengganan dan ketabuan terhadap penulisan telah berubah menjadi kemustian. Sebagaimana pengakuan al-Zuhrī, ketika dia telah menuliskan hadis kepada penguasa dan menuturkan: "kami benci menulis ilmu (hadis) sampai para penguasa meminta kami untuk menuliskannya. Selanjutnya kami sadar bahwa tak ada seorangpun di kalangan umat Islam yang menentang hal itu." ${ }^{57}$ Nampaknya pada periode ini sudah merasakan pentingnya penulisan hadis dan sudah memahami kelemahan dari kekhawatiran 'Umar ibn Khațtab akan adanya kitab tandingan selain alQuran dengan mengibaratkan pada ahl al-kitāb sebelum Islam. Suatu analog yang tidak kompetabel antara kedudukan hadis terhadap al-Quran yang jelas sudah mendapat legitimasi dari wahyu dengan kedudukan Maśnat kaum Yahudi yang sengaja dibuat sebagai tandingan kitab Taurat. Sebagaimana yang dituturkan oleh Dahhaj ibn Muzahhim: "jangan samakan catatan hadis dengan lembaran-lembaran Maśnat. ${ }^{58}$ Selain itu terdapat perbedaan mendasar antara Maṡnat yang merupakan kumpulan fatwa atau pendapat para ahli hukum Yahudi yang tidak memiliki otoritas, sementara hadis memiliki otoritas yang independen. ${ }^{59}$

Meskipun manfaat penulisan hadis sangat dirasakan di kalangan umat, namun upaya penghimpunan hadis baru terealisir pada paroh kedua abad kedua hijriyah, 'Abd al-Razzāq menuturkan bahwa orang pertama yang mengumpulkan hadis adalah 'Abd al-Malik ibn Jurayj (w. 150/767) dan 'Abd al-Raḥmān al-Awzā'i (w. 157/773).60 Al-Żahabi menulis bahwa pada masa itu para ulama mulai mencatat hadis, fiqh, dan tafsir, di antaranya adalah Jurayj di Makkah, Anas ibn Malik di Madinah, Muammar di Yaman, dan Sufyān al-Sawrī (w.167) di Kufah.61 Pada pertengahan abad kedua perhatian para ulama banyak dicurahkan pada penghimpunan hadis-hadis Nabi di luar fatwa sahabat dan tabi'in dalam bentuk Musnad. Adapun Musnad pertama adalah karya Abū Dawd alṬayalisi dan Musnad Ahmad ibn Hanbal.62 Penyusunan ini terus berlanjut 
dengan tersusunnya kitab-kitab yang memuat hadis-hadis sahih yang dikenal dengan 'Kutub Sittah'. Sementara pada generasi setelahnya lebih bersifat pada upaya memberi komentar dan penjelasan atau ulasan dari kitab-kitab yang sudah ada.

Meskipun penulisan hadis mengalami keterlambatan sampai pertengahan abad III $\mathrm{H}$, namun bukan berarti autentisitas dan validitas hadis menjadi suatu yang mustahil, karena ulama belakangan berupaya secara serius dalam melakuan verifikasi. Terbukti terdapat banyak karya yang memuat kritik, baik dari aspek jaringan transmisi dengan selektivitas para periwayat maupun dari aspek meteri hadis sebagai upaya membentengi dan membendung hadis-hadis palsu. Adapun faktorfaktor yang menunjang kemurnian hadis adalah: pertama, adanya ikatan emosional uat Islam untuk perpegang teguh segala sesuatu yang datang dari Nabi. Kedua, tradisi kekuatan hafalan para ulama dalam proses transmisi hadis. Ketiga, sikap kehati-hatian terhadap hadis dari upaya pemalsuan. ${ }^{63}$ Hal ini ditunjang oleh sikap selektivitas para pertiwayat dalam periwayatan, sebagaimana 'Uqbah seorang tabi'in menganjurkan anaknya untuk tidak menerima hadis kecuali dari periwayat yang siqat. Keempat, terdapatnya beberapa peninggalan manuskrip yang berisi tentang hadis-hadis. Kelima, adanya majlis-majlis ilmu yang dilaksanakan oleh para ulama otoritatif dalam transformasi hadis. Keenam, adanya penyebaran ajaran Nabi ke berbagai wilayah oleh para duta yang diutus para penguasa. Ketujuh, sikap komitmen dari para ulama dalam meriwayatkan hadis dengan ditunjang oleh sikap regiusitas yang tinggi.

Lain halnya dengan sistem pemeliharaan hadis di kalangan Syi'ah. Dengan konsep kepemimpinan yang eksklusif, golongan ini hanya menerima hadis yang diriwayatkan dari para Imām ma'ṣūm. ${ }^{64}$ Dalam kenyataannya, kaum Syi'ah merupakan mazhab utama dalam Islam, yang secara doktrinal berbeda dari kalangan ortodoks muslim, ternyata memiliki kumpulan hadis yang sama sekali berbada. ${ }^{65}$ Sumber hadis bukan saja sebatas dari ucapan dan perbuatan Nabi, tetapi mencakup seluruh ucapan dan perilaku para Imām mașūm, termasuk ucapanucapan Fatimah binti Muhammad, karena masuk dalam khitab ahl bayt Nabi yang dijamin kesuciannya oleh wahyu. ${ }^{66}$

Golongan Syi'ah beranggapan bahwa mereka sejak awal telah memelihara hadis melalui tulisan. Berawal dari anjuran Nabi untuk 
menuliskan hadis dianggap sebagai perintah yang sangat penting dan dilanjutkan oleh para Imām. Ummu Salamah meriwayatkan: "Nabi meminta adim (kulit domba yang telah disamak) untuk dibawa, 'Ali pada saat itu bersama Nabi, lalu beliau mendiktekan begitu banyak hadis kepada 'Ali, sehingga kedua sisi kulita domba tersebut penuh dengan tulisan."67 Pada kesempatan lain Ummu Salamah meriwayatkan: seorang telah bertanya kepada 'Ali tentang bagaimana ia mampu meriwayatkan hadis lebih banyak dibanding para sahabat lain, 'Ali menjawab, "Ini karena setiap aku bertanaya kepada Nabi, ia selalu menjawab dan jika aku diam, ia sendiri yang memulai berbicara."68 Fenomena tersebut menunjukkan adanya tradisi penulisan hadis sejak awal, berbeda dengan kalangan Sunni yang terdapat kontradiksi terhadap kebolehan penulisan hadis.

Tradisi penulisan hadis diwariskan kepada para Imām penerus secara turun-temurun, sebagaimana nasehat 'Ali kepada Hasan untuk memelihara ilmu melalui tulisan. ${ }^{69}$ Demikian halnya nasehat Hasan Ibn 'Ali kepada anaknya menganjurkan hal yang sama. ${ }^{70}$ Al-Hakam ibn Utaybah membincangkan suatu masalah kepada Imām al-Bāqir, ketika terjadi perselisihan, maka ia meminta anaknya (Imām Ja'far) untuk mengambil sebuah kitab, setelah dibawakan buku besar, lalu dibuka-buka kemudian menemukan masalahnya, kemudian ia berkata: "ini adalah tulisan tangan 'Ali sendiri yang didiktekan oleh Rasulullah." 71 Abū Ḥanifah memberi julukan Imām Ja'far dengan " kutubi." Sistem periwayatan dan klasifikasi hadis-hadis alam Syi'ah tidak jauh berbeda dengan kalangan Sunni. Namun kriteria penilaian seorang periwayat terdapat perbedaan, terutama tentang komitmen periwayat dalam bertasyayu'.

Adapun kitab kumpulan hadis yang ada di kalangan Syi'ah adalah: al-Kahfi karya Abū Ja'far Muhammad ibn Isḥaq al-Kulayni, ${ }^{72}$ Man la Yad\}urruhu al-Faqīh karya al-Ṣadiq, al-Tahżīb karya al-Ṭūsī, Wasāil alSyi'ah karya al-Hurr al-'Amilī, dan kitab Bị̣ār al-Anwār karya Majlis Muhammad al-Baqir. Kitab-kitab tersebut bersumber dari kitab induk "Ușūl Arba Mi'ah" yaitu kitab Imām 'Ali yang diwariskan kepada generasi berikutnya sampai Imām Muhammad Hasan al-Askari. ${ }^{73}$ Para Imām juga memiliki otoritas sebagai sumber hadis yang dikumpulkan dalam kitabkitab di atas, terutama dalam kitab Biḥ̄ar al-Anwār.

\section{Peran Periwayat (Transformer)}


Keseriusan dalam pemeliharaan hadis sejak awal tidak pernah surut sampai terkodifikasikan dalam bentuk kitab-kitab hadis standar. Upaya dalam menjaga kemurnian hadis, para ulama selalu selektif dalam menerima dan meriwayatkan hadis. Madinah sebagai rumah sunnah (dār al-sunnah) merupakan tempat proses pemeliharaan sunnah yang paling dinamis yang tercermin dalam kehidupan komunitas Madinah. Pada periode awal para sahabat saling tukar menukar informasi segala sesuatu yang datang dari Nabi baik dalam bentuk lisan maupun peneladanan langsung. Demikian halnya pada periode tabi'in dan generasi selanjutnya. Fenomena tersebut sangat kental dengan tradisi Madinah, sehingga tidak mengherankan para tokoh periwayat hadis terbanyak dari Madinah. ${ }^{74}$ Pada perkembangan selanjutnya Madinah mewariskan tradisi yang lebih mapan, sehingga amal komunitas Madinah memiliki otoritas tersendiri bagi standar kehidupan keagamaan. ${ }^{75}$

Berbeda halnya dengan daerah-daerah yang secara geografis letaknya jauh dari Madinah, tradisi setempat telah mempengaruhi isu-isu keagamaan yang sedang berkembang. Ketika mendapatkan sesuatu yang datang dari Nabi, mereka mengalami kesulitan dalam memastikan dan mengecek kebenaran hadis tersebut. Realitas inilah yang membuat para ulama lebih berhati-hati dalam menyeleksi hadis-hadis Nabi, mereka tidak meriwayatkan hadis kecuali dari seorang periwayat yang siqat. Untuk mendapatkan keabsahan suatu hadis, para ulama lebih mengutamakan pertemuan langsung dengan periwayat otoritatif sebagai sumber periwayatan. Tersebarnya para sahabat dan tokoh-tokoh otoritatif dalam hadis di beberapa pusat-pusat perkembangan Islam di beberapa kawasan, pertemuan langsung terhadap para periwayat otoritatif mengharuskan adanya pengembaraan dalam mendapat seorang yang otoritasnya sudah dikenal. Makkah menjadi posisi yang strategis bagi bertemunya para tokoh dari berbagai kawasan secara langsung malalui ibadah haji. Kesempatan baik ini biasanya dijadikan sarana untuk mengadakan penngecekan terhadap beberapa catatan hadis kepada tokoh-tokoh yang kompeten. ${ }^{76}$ Pertemuan tahunan dirasa tidak cukup bagi penngecekan keabsahan hadis yang telah mengalami perkembangan yang tak terkendali. Kebetuhan mendesak ini selanjutnya tradisi pengembaraan menjadi trend dan kebanggaan baru di kalangan ulama hadis. Pada perkembangan selanjutnya, fenomena pertemuan langsung 
dengan periwayat otoritatif dan lebih awal menjadi prasyarat bagi keabsahan sebuah hadis yang diriwayatakan oleh seseorang. Intensitas yang tinggi untuk mendapatkan hadis dari periwayat otoritatif akan memperkuat keabsahan hadis yang diriwayatkan, Ibn Khaldun memberi komentar bahwa perolehan hadis secara langsung dengan secara lisan memiliki kekuatan hukum yang lebih kuat. ${ }^{77}$ Dalam penelitian kritik jaringan transmisi hadis sangat menentukan bagi terjaminnya ketersambungan sanad.

Tradisi pengembaraan dalam mencari hadis membutuhkan biaya dan waktu yang cukup banyak, Jabir ibn Abdullah misalnya, telah membeli seekor onta kemudian bepergian selama satu bulan hingga sampai Syam untuk menanyakan hadis tentang qișaș kepada Abdullah ibn Malik. Sa'îd ibn Musayyad menuturkan: "Saya mengembara berhari-hari hanya untuk mendapatkan sebuah hadis." 78 Bahkan ada yang berjalan kaki, seperti 'Abd Allāh ibn Abd al-Ghanī.79 Ada juga yang mengadakan perjalanan selama bertahun-tahun seperti yang dilakukan oleh Mufid ibn al-Barakah ibn al-Mubārak telah mengembara selama 15 sampai 20 tahun. ${ }^{80}$ Dampak dari tradisi pengembaraan ternyata sangat besar dalam memperkuat ikatan persaudaraan di kalangan umat Islam yang sedang mengalami perkembangan. di samping terjadi tukar menukar informasi tentang hadis, juga terjadi pembauran dan transformasi ajaran Islam secara menyeluruh. Setelah hadis-hadis terkodifikasi dalam bentuk kitabkitab standar baku, tradisi pengembaraan dalam mencari secara alamiah terhenti.

Imbas pengembaraan juga menimbulkan masalah negatif terhadap motif pemalsuan hadis. Pada perkembangan selanjutnya, situasi semacam itu dimanfaatkan oleh sebagian orang untuk mendapatkan keuntungan materi dan mendapatkan prestise. Pengorbanan dalam pencarian hadis telah menebabkan sebagian periwayat tidak memberikan informasi tentang hadis, kecuali dengan imbalan sejumlah uang. Hadis menjadi komoditas bagi sebagian orang dan menjadi sesuatu yang sangat berharga, sehingga hanya orang kayalah yang bisa mendapatkan lebih banyak hadis. Kondisi ini memunculkan istilah yang beredar di kalangan para ulama hadis, yaitu ambilah hadis dari orang kaya dan jangan mengambil hadis satupun dari seorang miskin. ${ }^{81} \mathrm{Hal}$ ini cukup rasional, mahalnya informasi tentang hadis, hampir orang miskin tidak mungkin 
mertiwayatkannya, sehingga periwayatannya dapat dianggap pemalsuan. Kondisi semacam ini juga dapat dijadikan standar dalam penilaian terhadap kualitas dan karakteristik para ulama berkenaan dengan keihlasan dalam meriwayatkan hadis yang diperolehnya. Sebagaimana Khummaid menolak pemberian hadiah dari seseorang yang meriwayatkan hadis darinya. ${ }^{82}$ Ahmad ibn Hanbal menolak periwayatan hadis dari seorang yang memperdagangkannya.83 Indikasi-indikasi tersebut dapat dijadikan sarana dalam penilaian (al-Jarh wa al-Ta'dīl) terhadap para periwayat.

Otentifikasi hadis menjadi lebih mapan dan baku setelah upaya selektifitas hadis terformulasi dalam bentuk kodifikasi berupa kitab-kitab yang memuat hadis-hadis yang dianggap absah. Upaya tersebut diawali pada generasi ketiga yaitu paroh pertama abad kedua hijriyah yang dimotori oleh Imām Anas ibn Mālik dengan karyanya al-Muwatța'.84 Untuk generasi keempat adalah Ahmad ibn Ḥanbal (164-241H) yang telah menyeleksi hadis dari 750.000 menjadi 40.000 hadis dalam sebuah musnad. Akan tetapi kumpulan hadis-hadisnya masih bercampur antara hadis sahih, hasan dan lemah.85 Selanjutnya Imām Bukhārī (194-256 H) telah berguru kepada seribu orang dan menghafal sekitar 100 ribu hadis șạ̣ịh dan 200 ribu hadis tidak șaḥih. Koleksi hadis-hadis yang telah diseleksi tertuang dalam karyanya al-Jāmi' al-Ṣaḥịh. ${ }^{86}$ Demikian halnya Imām Muslim mengumpulkan hadis-hadis yang telah diseleksi dalam sebuah kitab al-Jāmi' al-Ṣaḥ̂h, Terdapat koleksi-koleksi lain yang memiliki kualitas keabsahan lebih rendah yang tertuang dalam bentuk sunan diantaranya karya-karya Imām al-Tirmiżì, al-Nasā'ì, dan Abū Dāwūd. Setelah terkodifikasi dalam bentuk kitab-kitab di atas rujukan hadis telah beralih, tidak lagi kepada seorang ulama otoritatif, tetapi kreteria keabsahan hadis diukur dari kitab apa hadis tersebut diambil. Dalam hal ini, karya Bukhārī menempati urutan pertama, karena memiliki kriteria yang paling ketat dalam menetapkan suatu hadis yang akan ditulis.

Aktivitas pemeliharaan hadis pada generasi berikutnya lebih bersifat merujuk pada kitab-kitab hadis yang sudah dianggap standar, dengan memberi komentar dan penjelasan, sebagaimana upaya Ibn Hajar al-Asyqalāni memberi penjelasan kitab al-Bukhārī dalam karyanya Fatḥ al-Bāri. Demikian halnya para ulama lain berupaya memberi komentar dan penjelasan kitab-kitab hadis yang ada. Upaya lain yang dilakukan oleh 
para ulama hadis adalah dengan mengklasifikan secara tematik, sesuai dengan masalah yang sama. Adapun untuk mempermudah dalam mengetahui keabsahan sebuah hadis, para ulama berupaya menformulasikan rumusan-rumusan metodologi kritik sebagai upaya dalam mengklasifikasi dan penilaian hadis yang terangkum dalam kitabkitab 'Ulūm al-Hadīs̀.

\section{Pendapat Sarjana Tentang Penulisan Hadis}

Fenomena proses pemeliharaan hadis mendapat perhatian khusus dan menjadi bahan kajian yang serius di kalangan sarjana Barat. Sejak paroh kedua abad kesembilan belas, mereka telah menaruh perhatian pada metodologi kritik hadis, namun kajian mereka masih terfokus pada kritik materi hadis (matan) melalui analisis kerangka teori sejarah. Secara umum, mereka berpendapat bahwa dalam perkembangan hadis telah terjadi banyak karya yang tidak sesuai dengan tradisi awal. Hal ini belum ditambah dengan adanya hadis-hadis ajaib yang berlebihan dan tidak masuk akal.87 Pada dasarnya kesimpulan yang mereka ambil mengarah pada sikap skeptis yang berlebihan terhadap keabsahan hadis sebagai sesuatu yang datang dari Nabi. Formulasi hadis yang ada merupakan manifestasi dari perkembangan pemikian dan politik Islam yang mengkristal dalam berbagai mazhab. Dengan demikian batang tubuh hadis terus mengalami pembengkakan seiring dengan perkembangan mazhab teologi dan fikih. ${ }^{88}$ Atau dengan kata lain, hadis tidak lebih dari hasil pemikiran bebas para ulama, kemudian mereka menyandarkannya kepada Nabi untuk mendapat legitimasi dari pendapat mereka tersebut.

Dengan mengarahkan penelitian pada materi hadis, tesis Ignaz Goldziher menyebutkan bahwa hadis-hadis yang disandarkan pada Nabi dan para sahabat yang terhimpun dalam kumpulan hadis-hadis klasik adalah bukan merupakan laporan yang autentik, tetapi merupakan refleksi doktrinal dari perkembangan politik selama dua abad pertama sepeninggal Muhammad.89 Baginya, hampir-hampir tidak mungkin bahkan setipis keyakinan untuk menyaring sedemikian banyak materi hadis, sehingga dapat diperoleh suatu bagian yang dapat dinyatakan sebagai asli dari Nabi atau generasi sahabat awal. Untuk itu hadis harus dianggap sebagai catatan dan pandangan-pandangan serta sikap-sikap generasi muslim abad kedua hijiriyah, ketimbang sebagai catatan tentang kehidupan dan ajaran Nabi bahkan sahabat.90 Kumpulan hadis yang 
diperkenalkan pada abad ketiga hijriyah adalah untuk membuktikan relevansi hadis terhadap hukum. Struktur kitab hadis (al-Jāmi' al-Saḥịh) bukan merupakan hadis-hadis yang murni.91 Selanjutnya Goldziher menunjukkan bahwa materi hadis banyak dipengaruhi oleh pemikiran non Islam, yaitu ajaran-ajaran injil banyak diadobsi dalam sabda Nabi. ${ }^{92}$ Kesimpulan ini tidak jauh berbeda dengan koleganya baik Margoliouth dan Lammens yang berkesimpulan bahwa sunnah yang dipraktekkan oleh komunitas muslim generasi ketiga bukanlah peninggalan Nabi, melainkan kebiasaan masyarakat sebelum Islam yang telah dimodifikasi. ${ }^{93}$

Sebutan Madinah sebagai rumah sunnah tidak lepas dari sorotan Goldziher, menurutnya, komunitas Madinah banyak diwarnai oleh etik dan asketisisme Romawi, hukum Yahudi dan Kristen banyak tertuang dalam materi hadis yang merupakan sinkritisme Islam awal yang paling monumental. ${ }^{94}$ Dalam risetnya, dia juga menyebutkan bahwa sejarah awal pemikiarn Islam adalah merupakan hasil perhelatan dua kelompok, ahl alra'y (the partisans of opinion) dan ahl al-ḥadīs (the partisans of hadith), konflik tersebut menimbulkan banyak pemalsuan hadis. ${ }^{95}$ Di samping itu dia mencoba menggoyahkan otoritas al-Zuhrī sebagai juru kunci keabsahan hadis. Dia mencatat bahwa metode yang dipakai al-Zuhrī dalam menggabungkan laporan-laporan hanya mengikuti seleranya sendiri. ${ }^{96}$ Al-Zuhrī sebagai penulis hadis pertama, disebutkan bahwa hadis-hadis yang ditulis lebih berasal dari karangannya sendiri sebagai pesanan penguasa ketimbang dari generasi sebelumnya. ${ }^{97}$

Dengan mengarahkan penelitannya pada aspek sanad, J. Schacht mengadopsi hipotesis Goldziher, dia berkesimpulan bahwa anggapan diktum keNabian mungkin telah diambil dari hukum Romawi. Lebih jauh dia mengklaim bahwa sistem hukum secara pasti tidak sesuai dengan alQuran. ${ }^{98}$ Schacht menyebutkan bahwa anggapan bahwa Madinah sebagai rumah sunnah hanyalah fiksi pada generasi abad ketiga hijriyah, karena hal tersebut tidak dikenal pada akhir abad kedua hijriyah. ${ }^{99}$ Sikap skeptis terhadap keabsahan hadis dari aspek jaringan transmisi juga diungkapkan oleh Juynboll.100 Meskipun demikian, ia memiliki kesimpulan yang berbeda dari periode sebelumnya, yang menyebutkan bahwa hadis paling tidak sudah muncul pada awal abad ketujuh masehi (701-720 M) atau sekitar tahun 80-an hijriyah. ${ }^{101}$ 
Kajian serius terhadap jaringan transmisi hadis dilakukan oleh Robson, terdapat banyak artikel yang terkonsentrasi pada penelitian sanad. Dalam kajiannya dia berpendapat bahwa kitab-kitab hadis yang paling memuat jaringan transmisi secara lengkap adalah kitab musnad karya al-Ṭayālisi (w. 203 atau 204H), selanjutnya musnad Ahmad ibn Hanbal (w. 241 H). ${ }^{102}$ Meskipun dia meyakini banyak terjadi perubahan dalam hadis, namun dia percaya bahwa materi dalam tubuh hadis nampaknya asli berasal dari generasi awal. ${ }^{103}$ Demikian halnya Dozy percaya bahwa paling tidak seporah dari koleksi hadis Bukhari adalah absah. ${ }^{104}$ Kajian hadis di Barat telah mengalami perkembangan yang lebih menggembirakan, terutama dengan munculnya banyaknya tokoh dalam bidang ini. Nampaknya realitas Barat yang lebih demokratis memungkinkan adanya proses dialogis ide yang lebih terbuka dan kondusif. Terbukti munculnya perkembangan teori dalam kajian hadis, teori pertama muncul adalah common link yang dipelopori oleh Goldziher, Schacht, dan diikuti oleh banyak tokoh lain. Dari teori tersebut menghasilkan kesimpulan bahwa hadis muncul pada awal abad ketiga hijriyah. Teori ini dikembangkan oleh Juynboll dan menghasilkan teori particular cammon link yang bermuara pada kesimpulan bahwa hadis muncul pada awal abad ke-delapan masehi atau sekitas tahun 80-an hijriyah. Teori lain adalah projecting back, teori ini sebenarnya mengambil cara kerja para sarjana muslim dalam kritik transmisi hadis. Dari teori ini, paling tidak materi hadis sudah muncul pada masa awal Islam.

Meskipun terdapat perkembangan dalam kajian Islam di Barat yang mengarah pada kajian yang lebih obyektif, tetapi kajian-kajian yang ada masih terkungkung pada kerangka paradigma historis yang hanya memperhatikan fakta positif, dan hanya mendekati Islam melalui karangan tertulis yang dianggap berasal dari para pemikir Islam yang besar dan mewakili. Dengan demikian, mereka mengabaikan apa yang hanya diungkapkan secara lisan. ${ }^{105}$ Menghadirkan data-data sejarah sebagai alat analisa adalah sangat valid, namun jika data-data parsial dijadikan rujukan utama untuk menjeneralisir permasalhan yang lebih luas sangatlah tidak memadahi.

\section{E. Penutup}

Proses transmisi hadis telah melalui perjalanan sejarah panjang sampai terkukuhkan dalam bentuk kodifikasi kitab-kitab kumpulan hadis 
standar sebagai sumber otoritatif kedua setelah al-Quran. Pada awalnya manifesatsi hadis tanpa dukungan isnād, transmisi hadis lebih bersifat peneladanan langsung tanpa melibatkan rumusan-rumusan verbal. Formalisasi hadis sebagai konsekunsi logis dari perkembangan orientasi praktis keagamaan di kalangan komunitas Islam yang sedang mengalami pertumbuhan. Tradisi lisan dalam transmisi hadis tidak menafikan terdapatnya aktivitas penulisan. Fenomena pemalsuan hadis akibat interfensi pendapat-pendapat pribadi dalam batang tubuh hadis yang dilatarbelakangi oleh pertentangan antar faksi politik dan aliran keagamaan menumbuhkan sikap kehati-hatian dalam proses selektifitas periwayatan hadis. Fenomena tersebut juga melahirkan tradisi pengembaraan dalam upaya cek dan recek keabsahan sebuah hadis. Tradisi kritik terhadap para periwayat menjadi kriteria penting dalam mengecek validitas hadis yang diriwayatkan yang terformulasi dalam rumusan-rumusan kritik sanad.

Formalisasi penulisan hadis pada awal abad kedua hijriyah telah merubah orientasi pemeliharaan hadis. Seiring dengan munculnya hadis secara besar-besaran, ilmu-ilmu tertulis yang formal mulai dirintis. Kristalisasi tradisi penulisan hadis adalah dengan hadirnya beberapa karya yang memuat kumpulan hadis sebagai hasil upaya selektif dari masing-masing tokoh. Terdapat keseragaman corak penulisan hadis yang diwarnai oleh isu-isu keagamaan yang berkembang terutama masalahmasalah fikih. Standarisasi kritik sanad mengalami perkembangan yang tidak kalah pesatnya dengan upaya penulisan hadis dengan berbagai formulasinya.

Kajian hadis di kalangan sarjana Barat masih diwarnai epistimologi klasik Barat yang dilandasi oleh sikap skeptis dan tendensi-tendensi subyektif. Meskipun harus diakui bahwa secara metodologi telah melampaui praktek ilmiah kalangan sarjana muslim. Orientasi mereka dimotifasi oleh semangat untuk membuktikan bahwa materi hadis bukanlah bersumber dari Nabi, tetapi sebagai isu-isu yang berkembang di kalangan kumunitas muslim sepanjang dua abad pertama hijriyah. Di samping itu, mereka ingin membuktikan bahwa hadis-hadis tidak lebih dari hasil karangan para tokoh-tokoh kunci periwayat hadis yang menyandarkan kepada Nabi untuk mendapat legetimasi keagamaan. [] 


\section{DAFTAR PUSTAKA}

'Abd al-Razzāq, Tamhīd li Tārīkh al-Islāmiyah, jil. IX, Kairo: Lajnah al-Ta'līf wa al-Tarjamah wa al-Nasyr, 1966.

'Azmi, M. M., Hadis Nabi dan Sejarah Kodifikasinya, terj. Musthafa Ya'qub, Jakarta: Pustaka Firdaus, 1994.

Abbott, Nabia, Studies in Arabic Literary Papyri, Quranic Commentary and Tradition, jil. II, Chicago: Chicago University Press, 1967.

Abū Ubaydah, Gharīb al-Hadīś, Haydarabat: Dār al-Ma'ārif al-'Uśmāniyah, $1384 \mathrm{H}$.

Abū Yūsuf, Kitāb Kharrāj, Kairo: Dār al-Ma'ārif, 1202 H.

Abū Zahu, Muhammad, al-Hadīs wa al-Muhaddiṡūn, Beirūt: Dār al Fikr, t.th.

Arkoun, Mohammed, Nalar Islami dan Nalar Modern: Berbagai Tantangan dan Jalan Baru, Jakarta: INIS, 1994.

Askarī, Al-'Allāmah Sayyid al-Murtaḍa, Ma'ālim al-Madrasatayn, jil. III, Teheran: Mu'assasah al-Bi'śah, 1991.

Baghdādi, al-Khațīb, Taqyīd al-'Ilm, Kairo: Dār Iḥyā' al-'Arabi, 1074 H.

Baghdādi, al-Khațīb, al-Kifāyah fĩ al-'Ilm al-Dirāyah, Haydarabat: Dā'irah al-Ma'ārif al-Islāmiyah, $1313 \mathrm{H}$.

Bukhārī, Muḥammad Ismā'īl, Ṣahīḥ al-Bukhārī, jil. V, Beirūt: Dār al-Fikr, t.th.

Crone, Patricia, and Martin Hinds, Caliph: Relegions Authoruty in the First Century of Islam, Cambridge: Cambridge University Press, 1986.

Darimī, Ibn Bahran, Abū Muhammad 'Abd Allāh, Sunan, jil. II, Beirūt: Dār al-Fikr, $1405 \mathrm{H}$.

Gharāyā, Muhammad Yūsuf, "Historical Background of the Compilation of the Mu'atta' of Malik b. Anas" dalam Islamic Studies, vol. VII, No. 4, Pakistan: Islamic Research Institute, 1968.

Goldziher, Ignaz, Muslim Studies, jil. II, London: George Allen \& Unwin, 1971.

Ḥussain, Sayyid Muhammad Riḍa, Tadwīn al-Sunnah al-Syarīf, Libanon: Dār al-Hādi, 1413 H.

Hind, al-Muttaki, Kanz al-Ummal, jil. I, Beirut: Dār al-Ma'ārif, 1972.

Ibn 'Abd al-Barr, Abū 'Umar Yūsuf, Jāmi' Bayān al-'Ilm wa Faḍluh, jil. I, Mesir: Dār al-Kutub al-Hadīs̀ah, 1975.

Ibn 'Abd al-Barr, al-Isti'āb fĩ asmā' al-Ṣaḥabah, jil.. II, Beirūt: Dār al_Fikr, 1979. 
Ibn 'Abd Allāh, Jābir, Tażkirah al-Huffaż, jil. I, Beirūt: Dār al-Qalam, 1968.

Ibn 'Ali al-'Abbās al-Najasy, Abū Ḥasan Aḥmad, Rijāl al-Najasy, Qūm: alDawārī, t.th.

Ibn As̀īr, Usd al-Ghābah fì Ma'rifat al-Ṣaḥābah, jil. III, Kairo: Dār al-Kutub al-Hadīsah, $1386 \mathrm{H}$.

Ibn Ḥajar al-Asyqalāni, Tahżìb al-Tahżīb, jil. XII, Beirūt: Dār al-Fikr, 1978. Ibn Khaldun, Muqaddimah, ttp: Dār al-Bayān, tth.

Ibn Sa'ad, Muhammad, al-Ṭabaqāt al-Kubrā, jil. III, Beirūt: Dār al-Ṣadr, t.th. Juynboll, G.H.A., Muslim Tradition Studies in Chronologi, Provenance and Authorship of Early Hadith, Cambridge: Cambridge University Press, 1983.

Juynboll, G.H.A., The Authenticity of the Tradition Literature; Discussions in Modern Egypt, Leiden: E.J. Brill, 1969.

Khaṭīb, Muhammad 'Ajjāj, 'Ușūl al-Hadīs 'Ulūmuh wa MușṬalaḥuh, Beirut: Dār al-Fikr, 1409/1989.

Khațīb, Muhammad 'Ajjāj, al-Sunnah Qabl al-Tadwīn, Beirūt: Dār al-Fikr, 1989.

Lecker, Michael, "Waqidi's Account on the Status of the Jews of Madinna a Study of Combined Report" dalam jurnal Near Eastern Studies, vol. 54. No. 1, Chicago: Chicago University Press, 1994.

Margoliuth, D.S., “On Moslem Tradition” dalam jurnal Moslem World, vol. VII. No. 2, ttp: Hartford Seminary Foundation, 1912.

Motzky, Harald, "The Musannaf of Abd al-Razzaq al-San'āni as Source of Ahadith of the First Century A.H" dalam jurnal Near Eastern Studies, vol. 50 No. 1, 1991.

Qardawi, Yusuf, Memahami Sunnah, Bandung: Mizan, 1994.

Qațțan, Manna' Khalil, Mabāḥiś fì 'Ulūm al-Qur'ān, Beirut: Dār al-Fikr, 1978

Rāzi, Abū Hakim, al-Jarh wa al-Ta'dīl, jil. I, Beirūt: Dār al-Turās̀ al-'Arabī, 1952.

Rahman, Fazlur, Islam, Chicago: Chicago University Press, 1979.

Rasyid, Daud, “Goldziher dan Sunnah" dalam Ma'rifahj: Jurnal Kajian Islam, vol. I, Jakarta: Yayasan Haramain, $1415 \mathrm{H}$.

Robson, James, "Isnād in Muslim Tradition" dalam Trancsaction, vol. XV, Hertford: Stepehen Austin \& Sons, 1955. 
Robson, James, "Standarts Applied Muslem Traditionists" dalam journal Bulettin of Royland Library, vol. 43, Manchester: Manchester University press, 1955.

Robson, James, "Tradition in Investigation and Classification" dalam The Moslem World, vol. XLI tahun 1951.

Robson, James, "Tradition: Investigation and Classification" dalam Muslim World, vol. XLI..

S.M. Yusuf, "The Sunnah as Transmission Development and Revision" dalam Islamic Culture, vol. XXXVII, No. 4, Haydarabat: The Islamic Culture Board, 1963.

Ṣāliḥ, Ṣubhi, 'Ulūm al-Hadīs wa al-Muḥaddiśūn, Beirūt: Dār al-'Ilm li alMalāyīn, 1988.

San'āni, Imla<' wa al-Mustamli', Beirūt: Dār al-Fikr, 1409 H.

Schacht, Joseph, "A Revaluation of Islamic Traditions" dalam Jurnal of Royal Asiatic Society, London: The Society, 1949.

Schacht, Josept, The Origins of Jurisprudence, Oxford: Oxford University Press, 1952.

Shāfi'ī, al-Umm, jil. VII, Beirūt: Dār al-Fikr, t.th.

Sibā'i, Musțafa, al-Sunnah wa Makānatuhā fì al-Tasyrī’ al-Islāmi, Damshiq: 1978.

Siddiqi, Zubayr, Hadith Literature: it's Orogin, Development, Special Feature and Criticism, Calcutta: Calcutta University Press, 1912.

Sou'yb, Joesoep, Orientalisme dan Islam, Jakarta: Bulan Bintang, 1985..

Suyūțī, Jalāl al-Dīn, Tadrīb al-Rāwi, jil. III, Madinah: al-Maktabat al'Ilmiyah, $1392 \mathrm{H}$.

Suyūṭī, Jalāl al-Dīn, Tārīkh al-Khulafä', Mesir: Mațba'āt al-Sa'ādah, 1952.

Wensinck, A.J., "the Importence of Tradition for the Study of Islam" dalam jurnal Moslem World, vol. XI, No. 3, 1921.

Wonsbrough, John, Quranic Stidies, Oxford: Oxford University Press, 1977.

Yasin Dutton, "Sunna, Hadith, and Madina Amal" dalam Jurnal of Islamic Studies, vol. 4 No. 1, Oxford: Oxford University Press, 1993.

Żahabī, Muhammad Ḥusayn, Tafsīr wa al-Mufassirūn, jil. I, Beirut: Dār alFikr, 1978.

Zarqanī, MuaṬṬa' Malik, jil. II, Beirūt: Dār al-Fikr, 1988. 


\section{Catatan Akhir}

Dalam sejumlah ayat, kaum muslimin diperintahkan untuk mematuhi perintah Allah dan rasul-Nya (lih.: QS. Ali 'Imrān [3]: 32, 132; al-Ḥasyr [59]: 3; alNisā' [4]: 193.

${ }^{2}$ Aktualisasi prinsip-prinsip dasar al-Quran yang bersifat teoritik dioperasionalisasikan oleh Muhammad melalui peneladanan (lih.: Yusuf Qardawi, Memahami Sunnah, Bandung: Mizan, 1994, h. 16).

${ }^{3}$ Imām Syāfi'ì', al-Umm, jil. VII, Beirūt: Dār al-Fikr, h. 271.

${ }^{4}$ Fazlur Rahman, Islam, Chicago: Chicago University Press, 1979, h. 271. Pada masa Nabi, tidak ada hierarki antara sunnah Nabi, sunnah sahabat, dan sunnah komunitas muslim secara umum (lih.: Patricia Crone dan Martin Hinds, Caliph: Relegions Authoruty in the First Century of Islam, Cambridge: Cambridge University Press, 1986, h. 43-57). 'Umar menyatakan bahwa baik keputusan Muhammad maupun Abū Bakar adalah sunnah (lih.: Muhammad Ibn Sa'ad, alTabaqāt al-Kubrā, jil. III, Beirūt: Dār al-Șadr, t.th, h. 248). Demikian halnya, komunitas sahabat menganggap bahwa keputusan 'Umar adalah sunnah (lih.: Abū Yūsuf, Kitāb Kharrāji, Kairo: Dār al-Ma'ārif, 1202 H, h. 46; Josept Schacht, The Origins of Jurisprudence, Oxford: Oxford University Press, 1952, h. 75).

${ }^{5}$ Jumlah sahabat yang mencapai sekitar 114.000 orang, mereka tersebar di berbagai kawasan. Dalam kehidupan keseharian, mereka memiliki profesi yang berbeda, tabiat, kecenderungan, dan kemampuan intelektual yang tidak sama (lih.: Muhammad Abū Zahu, al-Hadīs wa al-Muhaddišūn, Beirūt: Dār al Fikr, t.th, h. 52-54; Muhammad Husayn al-Żahabi, Tafsīr wa al-Mufassirūn, jil. I, Beirut: Dār al-Fikr, 1978, h. 59-61). Dengan demikian, tidak semua sahabat memiliki otoritas untuk berfatwa yang dapat dijadikan sebagai landasan hukum (lih.: Ibn Khaldun, Muqaddimah, ttp: Dār al-Bayān, tth, h. 446).

${ }^{6}$ Zubayr Siddiqi, Hadith Literature: It's Origin, Development, Special Feature and Criticism, Calcutta: Calcutta University Press, 1912, h. 2.

${ }^{7}$ Otoritas sarjana Barat dalam kajian hadis diilhami oleh gagasan Sir William Muir dan Ignaz Goldziher, karya-karya mereka membuat para pembacanya bersikap skeptis terhadap otentisitas hadis (lih.: D.s. Margoliuth, "On Moslem Tradition" dalam jurnal Moslem World, vol. VII. No. 2, ttp: Hartford Seminary Foundation, 1912, h. 121; G.H.A. Juynboll, The Authenticity of the Tradition Literature; Discussions in Modern Egypt, Leiden: E.J. Brill, 1969, h. 5).

${ }^{8} \mathrm{Abū}$ Zahu, al-Hadiss, h. 53.

${ }^{9}$ Muhammad 'Ajjāj al-Khațib, 'Ușūl al-Hadīs 'Ulūmuh wa Mușțalaḥuh,

Beirut: Dār al-Fikr, 1409/1989, h. 140.

${ }^{10}$ Ibn Sa'ad, Tabaqāt, jil. II, h. 14.

${ }^{11}$ Manna' Khalil al-Qattān, Mabāhis fi 'Ulūm al-Qur'ān, Beirut: Dār al-Fikr, 1978, h. 66. 'Ajjāj al-Khațib, 'Ușūl, h. 142.

${ }^{12}$ Ibn 'Abd al-Barr, al-Isti'ẩ fi Asmā' al-Ṣahabah, jil.. II, Beirūt: Dār al_Fikr, 1979, h. 366.

${ }^{13}$ Ṣubhi al-S̄āliḥ, 'Ulūm al-Hadīs wa al-Muhaddis̄ūn, Beirūt: Dār al-'Ilm li alMalāyīn, 1988, h. 24.

${ }^{14}$ Ibn Sa'ad, Tabaqāt, jil., V, h. 334.

${ }^{15}$ Ibn As̄īr, Usd al-Ghābah fí Ma'rifat al-Ṣahābah, jil. III, Kairo: Dār al-Kutub al-Hadīis ah, 1386 H, h. 233.

${ }^{16}$ Nabia Abbott, Studies in Arabic Literary Papyri, Quranic Commentary and Tradition, jil. II, Chicago: Chicago University Press, 1967, h. 6-32.

${ }^{17}$ M. M. 'Azmi, Hadis Nabi dan Sejarah Kodifikasinya, terj. Musthafa Ya'qub, Jakarta: Pustaka Firdaus, 1994, h. 132-440. 
${ }^{18}$ G.H.A. Juynboll, Muslim Tradition Studies in Chronologi, Provenance and Authorship of Early Hadith, Cambridge: Cambridge University Press, 1983, h. 1012.

${ }^{19} \mathrm{Abu}$ Sa'īd al-Khudrī meriwayatkan dua hadis tentang pelarang penulisan hadis, pertama tentang barang siapa yang menulis dari Nabi selain al-Quran maka harap menghapusnya. Kedua, Sa'īd minta izin untuk menuliskan hadis, namun dilarang oleh Nabi. Hadis yang lain diriwayatkan oleh Abū Hurairah ('Ajjāj al-Khațib, Ușūl, h. 147).

${ }^{20}$ Terdapat periwayatan yang melimpah tentang diperbolehkannya penulisan hadis termasuk diriwayatakan oleh Abu Hurairah yang tidak konsisten dalam hal ini (Selanjutnya lihat kutip dari 'Ajjāj al-Khațib, Ușūl, h. 147-149).

${ }^{21}$ Alasan tidak menulis hadis karena ditakutkan bercampur al-Quran sebenarnya tidak cukup rasional. Pertama, dari aspek bahasa al-Qur'an para sahabat yang sudah kental dengan tradisi syair akan mudah membedakan antara wahyu dan perkataan Nabi yang memiliki muatan yang lebih berat dan lebih padat. Kedua, selama Nabi masih hidup kesalahan dapat dicek secara langsung. Ketiga, terdapat banyak saksi di antara para sahabat yang kebanyakan penghafal al-Quran. Ketempat, lebih berdampak negatif ketika hadis tidak ditulis, karena orang lebih mudah memalsukan hadis di masa belakangan, ketimbang pemalsuan al-Quran.

${ }^{22}$ Ibid, h. 109.

${ }^{23} \mathrm{Abū}$ 'Umar Yūsuf ibn 'Abd al-Birr, Jāmi' Bayān al-'Ilm wa Fạ̣luh, jil. I, Mesir: Dār al-Kutub al-Hadīṡah, 1975, h. 36.

${ }^{24}$ Al-Khatīb al-Baghdādi, Taqyīd, h. 54.

${ }^{25}$ Abū Bakar meminta saksi kepada Mughirah yang meriwayatkan hadis tentang hak waris bagi seorang nenek, maka Muhammad ibn Maslamah memberikan kesaksian tentang kebenaran hadis tersebut (lih.: Zarqanī, Muatța' Malik, jil. II, Beirūt: Dār al-Fikr, 1988, h. 513.

${ }^{26 ،}$ Umar meminta saksi kepada Mūsa al-Asy'arī tentang salam tiga kali yang tidak dijawab, maka ditinggalkan. Untuk itu, 'Ubay ibn Ka'ab memberikan kesaksiannya (Muhammad Ismā'īl al-Bukhārī, Sahīh al-Bukhārī, jil. V, Beirūt: Dār al-Fikr, t.th, h. 88.

${ }^{27}$ Ahmad ibn Hanbal, Musnad, jil. I, h. 372.

${ }^{28 ،}$ Ajjāj al-Khațib, Ușūl, h. 153; al-Muttaki al-Hind, Kanz al-Ummal, jil. I, Beirut: Dār al-Ma'ārif́, 1972, h. 174. h. 53 .

${ }^{29}$ Al-Khațib al-Baghdādi, Taqyīd al-'Ilm, Kairo: Dār Ihyā' al-'Arabi, 1074 H,

${ }^{30}$ Ibid, h. 50. Ibn Sa'ad, Tabaqāt, jil., III, h. 206. Jalāl al-Dīn al-Suyūțī, Tadrīb al-Rāwi, jil. III, Madinah: al-Maktabat al-'Ilmiyah, 1392 H, h. 68.

'Ajjaj al-Khatib, Ușūl, h. 153.

${ }^{32}$ Ibid, h. 154-156.

${ }^{33}$ Abū Ubaydah, Gharīb al-Hadīs, Haydarabat: Dār al-Ma'ārif al-'Uśmāniyah, 1384 H, h. 48. Nabia Abbott, Studies in Arabic, h. 7-8.

${ }^{34} A b \bar{u}$ Muhammad 'Abd Allāh ibn Bahran al-Darimī, Sunan, jil. II, Beirūt: Dār al-Fikr, 1405, h. 116.

${ }^{35}$ Dapat dilihat dari jumlah hadis yang diriwayatkan oleh para sahabat, sebagaimana dalam Sunan Ahmad tercata bahwa hadis yang diriwayatkan dari Abū Hurairah sejumlah 313, dari 'Abd Allāh ibn 'Umar sejumlah 156, dan banyak dari kalangan sahabat lain. Sementara dari Abu Bakar hanya berjumlah 14, dari 'Umar 41, dan dari 'Ali sejumlah 85 (lih.: Muḥammad Yūsuf Gharāyā, "Historical 
Background of the Compilation of the Mu'atta' of Malik b. Anas" dalam Islamic Studies, vol. VII, No. 4, Pakistan: Islamic Research Institute, 1968, h. 380-381).

${ }^{36}$ Ibn Sa'ad, Tabaqāt, jil. I, h. 364.

${ }^{37}$ Ibid, jil. II, h. 119; al-Khațib al-Baghdādi, Taqyīd, h. 42.

${ }^{38}$ Ibn Ḥajar al-Asyqalāni, Tahżīb al-Tahżìb, jil. XII, Beirūt: Dār al-Fikr, 1978, h. 127

${ }^{39}$ Ibid, jil. XI, h. 67.

${ }^{40}$ Ibid, h. 461.

${ }^{41}$ Ibid, h. 258.

${ }^{42}$ Al-Khațib al-Baghdādi, Taqyīd, h. 42-43.

${ }^{43}$ Ibid, h. 44.

${ }^{44} \mathrm{Al}$-Dārimi, Sunan, h. jil. I, h. 22.

${ }^{45}$ Ibn Hajar al-Asyqalāni, Tahżīb, jil. VII, h. 157.

${ }^{46}$ Ibid, jil. V, h. 188.

${ }^{47}$ Șubhi al-Ṣãliḥ, 'Ulūm al-Hadīs, h. 41.

${ }^{48}$ Äl-Khatib al-Baghdādi, Taqyīd, h. 45.

${ }^{49}$ Ibid, h. 45-46.

${ }^{50} \mathrm{Ibid}$, h. 60.

${ }^{51}$ Ibn Sa'ad, Tabaqāt, jil. I, h. 190.

${ }^{52}$ Ibn 'Abd al-Barr, Jamī' Bayān, jil. I, h. 92.

${ }^{53}$ ‘jjjāj al-Khațib, Ușūl, h. 178.

${ }^{54}$ 'Abd al-Razzāq, Tamhīd li Tārīkh al-Islāmiyah, jil. IX, Kairo: Lajnah al-

Ta'līf wa al-Tarjamah wa al-Nașr, 1966, h. 337.

${ }^{55}$ Ibn Sa'ad, Tabaqāt, jil. III, h. 54.

${ }^{56}$ Subhi al-Șălih, 'Ulūm al-Hadìs, h. 46.

${ }^{57}$ İbn Sa'ad, Tảbaqāt, jil., Iİ, h. 389. Al-Khațib al-Baghdādi, Taqyīd, h. 107.

${ }^{58}$ Ibid, h. 47.

${ }^{59}$ D.S. Margoliauth, "On Mulim Tradition”, h. 117.

${ }^{60}$ Abū Hakim al-Rāzi, al-Jarḥ wa al-Ta'dīl, jil. I, Beirūt: Dār al-Turāś al'Arabī, 1952, h. 184.

${ }^{61}$ Jalāl al-Dīn al-SuyūṬì, Tārīkh al-Khulafā', Mesir: MaṬba'ât al-Sa'ādah, 1952, h. 261.

${ }^{62}$ Subhi al-Șālih, 'Ulūm al-Hadìs. h. 47.

${ }^{63}$ Muhammad 'Ajjaj al-Khatīb, al-Sunnah Qabl al-Tadwīn, Beirūt: Dār alFikr, 1989, h. 122.

${ }^{64}$ Berangkat dari doktrin yang didasarkan pada hadis saqalyn behwa para Imām dari keluarga Nabi tidak dapat dipisahkan dari al-Qur'an, sehingga secara prerogratif menjadi pewaris sah dalam kepemimpinan umat dan spiritual. Sayyid Muhammad Rị̣a Ḥussain, Tadwīn al-Sunnah al-Syarīf, Libanon: Dār alHādi, 1413, h. 119.

${ }^{65}$ Fazlur Rahman, Islam, h. 76.

${ }^{66}$ QS. al-Aḥāb [33]: 33.

${ }^{67}$ Al-San'āni, Imlā' wa al-Mustamli', Beirūt: Dār al-Fikr, 1409 H, h. 5.

${ }^{68} \mathrm{Ibn}$ Sa'ad, Tabaqāt, jil. VI, h. 220.

${ }^{69}$ Abū Muhammadal-Darimī, Sunan, jil. I, h. 130.

${ }^{70} \mathrm{Al}$-Kațīb al-Baghdādi, Taqyīd, h. 91.

${ }^{71}$ Abū Ḥasan Ahmad ibn 'Ali al-'Abbās al-Najasy, Rijāl al-Najasy, Qūm: alDawārī, t.th, h. 225.

${ }^{72}$ Kitab kumpulan hadis al-Kahfi memuat hadis-hadis sahih yang memiliki kedudukan sebagaimana kitab sahih karya al-Bukhari. Namun demikian secara 
obyektif kalangan Syi'ah menyebutkan prosentase kesulurahan hadis sahih dalam al-Kahfi tersebut.

${ }^{73}$ Al-'Allāmah Sayyid al-Murtaḍa al-Askarī, Ma'ālim al-Madrasatayn, jil. III, Teheran: Mu'assasah al-Bi'ṡah, 1992, h. 257.

${ }^{74}$ S.M. Yusuf, "The Sunnah as Transmission Development and Revision" dalam Islamic Culture, vol. XXXVII, No. 4, Haydarabat: The Islamic Culture Board, 1963, h. 276-279.

${ }^{75}$ Yasin Dutton, "Sunna, Hadith, and Madina Amal" dalam Jurnal of Islamic

Studies, vol. 4 No. 1, Oxford: Oxford University Press, 1993, h. 10-11.

${ }^{76}$ James Robson, "Tradition: Investigation and Classification" dalam

Muslim World, vol. XLI, h. 99.

${ }^{77}$ Ibn Khaldun, Muqaddimah, h. 541.

h. 53-54.

${ }^{78}$ Jābir ibn ‘Abd Allāh, Tażkirah al-Ḥuffaz, jil. I, Beirūt: Dār al-Qalam, 1968,

${ }^{79}$ Ibid, jil. IV, h. 149.

${ }^{80} \mathrm{Ibid}$, h. jil. II, 708.

${ }^{81}$ Al-KhaTTib al-Baghdādi, al-Kifāyah fĩ al-'Ilm al-Dirāyah, Haydarabat: Dā'irah al-Ma'āifi al-Islāmiyah, 1313, h. 150.

${ }^{82}$ Ibid, h. 153.

${ }^{83}$ Ibid, h. 54.

${ }^{84}$ Dalam kitab al-Muwatta' Imām Malik masih belum memisahkan antara hadis sahih dengan yang tidak sahih. Lihat 'Ajjāj al-Khațib, Ușūl, h. 309.

${ }^{85}$ Ibid, h. 328-329.

${ }^{86}$ Bukhārī telah menyeleksi 600.000 hadis menjadi 7.275 secara keseluruhan kumpulannya, dan sekitar 4000 jika tanpa diualng-ulang (lih.: James Robson, "Tradition in Investigation and Classification" dalam The Moslem World, vol. XLI tahun 1951, h. 100).

185.

${ }^{87}$ Joesoep Sou'yb, Orientalisme dan Islam, Jakarta: Bulan Bintang, 1985, h.

${ }^{88}$ Fazlur Rahman, Islam, h. 53.

1971 , h. 5 .

${ }^{89}$ Ignaz Goldziher, Muslim Studies, jil. II, London: George Allen \& Unwin,

${ }^{90}$ Ibid, h. 44.

${ }^{91}$ Ibid, h. 199.

${ }^{92}$ Ibid, h. 382.

${ }^{93}$ Fazlur Rahman, Islam, h. 55. Kesimpulan diatas juga digunakan dalam penelitian al-Qur'an yang menyebutkan bahwa al-Quran adalah sinkritisasi dari tradisi sebelumnya sebagai hasil asimilasi dari tradisi Yahudi dan Kristen (lih.: John Wonsbrough, Quranic Stidies, Oxford: Oxford University Press, 1977, h. 1925).

${ }^{94}$ A.J. Wensinck, "the Importence of Tradition for the Study of Islam" dalam jurnal Moslem World, vol. XI, No. 3 (1921), h. 244.

${ }^{95}$ I. Goldziher, Muslim, h. 77-85.

${ }^{96}$ Kasus yang diangkat Goldziher adalah berpijak pada periwayatan hadīs al-ifk dalam musnad Ibn Hanbāl. Selanjutnya lihat Michael Lecker, "Waqidi's Account on the Status of the Jews of Madinna a Study of Combined Report" dalam jurnal Near Eastern Studies, vol. 54. No. 1, Chicago: Chicago University Press, 1994, h. 19.

${ }^{97}$ Anggapan semacam itu banyak dibantah oleh para ulama, dukungan alZuhrī kepada penguasa lebih disebabkan oleh pertimbangan kewajiab sebagai 
warga negara yang sesuai dengan semangat Islam. Daud Rasyid, "Goldziher dan Sunnah" dalam Ma'rifah: Jurnal Kajian Islam, vol. I, Jakarta: Yayasan Haramain, 1415 H, h. 29-30. Argumentasi tersebut dibuktikan bahwa al-Zuhrī pernah menegur dengan memberi peringatan kepada khalifah Hisam ibn 'abd al-Malik berkenaan dengan tuduhannya kepada 'Ali sebagai pembohong. Muștafa alSibā'i, al-Sunnah wa Makānatuhā fì al-Tasyrī' al-Islāmi, Damsyiq: 1978, h. 215.

${ }^{98} \mathrm{Harald}$ Motzky, "the Musannaf of Abd al-Razzaq al-San'āni as Source of Ahadith of the First Century A.H" dalam jurnal Near Eastern Studies, vol. 50 No. 1, (1991), h. 18-19.

J. Schacht menunjukkan bahwa doktrin Madinah sebagai rumah sunnah adalah diawali oleh Imām Malik dalam Muatta' tidak sesuai dengan isnād Madinah, kecuali pada Malik sendiri. Hadis-hadis tersebut terkadang mengekspresikan doktrin-doktrin Iraq dan tidak mereprentasikan kebiasaan hukum Madinah (Joseph Schacht. "A Revaluation of Islamic Traditions" dalam Jurnal of Royal Asiatic Society, London: The Society, 1949, h. 144-145. Joseph Schacht, Origins, h. 64

${ }^{100}$ G.H.A. Juynboll, Muslim, h. 9-10.

${ }^{101}$ Ibid, h. 10-11.

${ }^{102}$ James Robson, "Standarts Applied Muslem Traditionists" dalam jurnal Bulettin of Royland Library, vol. 43, Manchester: Manchester University press, 1955, h. 451.

${ }^{103}$ James Robson, "Isnād in Muslim Tradition" dalam Trancsaction, vol. XV, Hertford: Stepehen Austin \& Sons, 1955, h. 25

${ }^{104}$ A.j. Wensinck, "The Importance of Tradition" h. 241.

${ }^{105}$ Mohammed Arkoun, Nalar Islami dan Nalar Modern: Berbagai Tantangan dan Jalan Baru, Jakarta: INIS, 1994, h. 7-8. 